\title{
Development of Islamic Values for Deaf Students at Little Hijabi Homeschooling
}

\author{
Rosalia Canida ${ }^{1}$, Dian ${ }^{1}$, Iin Hindasah Noor ${ }^{1}$ \\ Manajemen Pendidikan Islam, Universitas Islam Negeri Sunan Gunung Djati, Indonesia(1) \\ DOI: $10.31004 /$ obsesi.v6i3.1999
}

\begin{abstract}
Abstrak
Tujuan penelitian ini adalah untuk menganalisis pengembangan nilai-nilai islam pada siswa tuna rungu di The Little Hijabi Homeschooling; mempelajari nilai islam yang diterapkan pada siswa tuna rungu terutama pada anak usia dini; mengkaji faktor pendukung dan penghambat dalam penerapan nilai-nilai islam dan cara The Little Hijabi Homeschooling dalam mendidik serta mengembangkan kurikulum bernilai islam. Metode penelitian yang digunakan adalah metode deskriptif kualitatif serta studi pustaka. Teknik pengumpulan data dalam penelitian ini meliputi observasi, wawancara; dan dokumentasi; serta mencari data melalui website ataupun jurnal. Analisis data kualitatif yang digunakan dalam penelitian ini yaitu reduksi data, penyajian data dan penarikan kesimpulan. Dapat dikatakan bahwa pengembangan nilai islam terhadap sswa tuna rungu terutama siswa yang berusia dini sudah sangat baik dan berbeda dengan sekolah luar biasa yang digunakan para disabilitas pada umumnya yang hanya sebatas pembelajaran PAI semata tanpa ada pembelajaran mendalam dalam mengaplikasikan bentuk ketauhidan serta pembelajaran iqro dengan bahasa isyarat umumnya.
\end{abstract}

Kata Kunci: islam; tuna rungu; siswa

\begin{abstract}
The aims of this study were is to analyze the development of Islamic values for deaf students at The Little Hijabi Homeschooling; learn Islamic values applied to deaf students, especially in early childhood; examine the supporting and inhibiting factors in implementing the Islamic values and the way of The Little Hijabi Homeschooling in educating and developing Islamic values curriculum. The research method used was descriptive qualitative method and literature study. Data collection techniques in this study include is observation; interview; and documentation; searching for data through websites or journals. Qualitative data analysis used in this study with data reduction, data presentation, and drawing conclusions. It can be said that the development of Islamic values for deaf students, especially students at an early age, is very good and different from special schools used by people with disabilities in general which are only limited to PAI learning without any in-depth learning in applying the form of monotheism and Iqro learning with sign language.
\end{abstract}

Keywords: islam; deaf; students

Copyright (c) 2022 Rosalia Canida, et al.

पCorresponding author :

Email Address : rosalia.canida@gmail.com (Bandung, Indonesia)

Received 23 October 2021, Accepted 21 December 2021, Published 17 January 2022 


\section{INTRODUCTION}

Education is the right of every child. Not only for those who have perfection, not only for those who have wealth but that right can be accepted by all groups. For those who are less capable in terms of wealth, those who are less capable in terms of physical and are no exception. Children with special needs are one part of children who are less capable in terms of physical limitations. The guidance that is consciously carried out by educators to build and develop interests and talents that are useful in adapting themselves and society is called Education. Education is a process that has a purpose which is usually attempted to create certain behavior patterns in children or people who are being educated (Syaibani, 1979). From some of the definitions above, it can be concluded that education is a teaching and learning process that has the aim to be able to build and develop interests and talents so that it is useful for self-adjustment and society.

Every child can learn various lessons according to their growth and development of age. The drive to learn is human nature. Humans are categorized according to their developmental age. However, along with human development, some of them experience developmental delays. This results in a large reduction in potential because people with developmental disorders usually experience difficulties in the teaching and learning process. Therefore, children who experience this need adults who act as educators to help discover the potential that lies within themselves (Alimin \& Permanarian, 2005). For example, many toddlers who are deaf (hearing impairment) at pre-school age have not been able to demonstrate academic skills according to their age, but with the help of adults who act as educators in their environment, they can develop themselves through the learning process so that they can have good skills.

The limitations that Allah SWT gives to a person are the destiny of Allah SWT as Allah SWT wrote in Q.S An-Nuur verse 61, namely:

"It is no restriction upon the blind, and it is no restriction upon the lame, and it is no restriction upon the sick, nor upon yourselves, that you eat from your houses, or from your fathers' houses, or your mothers' houses, or your brother's houses, or your sisters' houses, or the houses of your paternal uncles, or the houses of your paternal aunts, or the houses of your maternal uncles, or the houses of your maternal aunts, or that of which you possess the keys, or of your friend. It is no fault in you that you eat all together or in diverse groups. So when you enter houses, salute one another (Literally: salute yourselves) with a greeting from the Providence of Allah, blessed and good. Thus Allah makes evident to you the signs that possibly you would consider." (QS. An-Nur: 61)

It is clearly stated in the verse that people with disabilities must have the same rights as other human beings. As a Muslim, there is no different and must fulfill the rights of one Muslim with another Muslim regardless of whether he/she has limitations. Islam is a perfect religion, Allah SWT explains that humans are created in the same and equal conditions. One thing that can distinguish them is the aspect of piety. This is in line with QS Al-Hujurat verse 11, namely "O you who believe, no men should ever scoff at other men. May be, the latter are better than the former. Nor should women (ever scoff) at other women. May be, the latter women are better than the former ones. And do not find fault with one another, nor call one another with bad nicknames. Bad is the name of sinfulness after embracing Faith. If anyone does not repent, then such people are the wrongdoers." (QS. Al-Hujurat:11)

As for the Hadith of the Prophet Muhammad

"Verily Allah does not look at your faces and your wealth, but He looks to your deeds and your hearts." (Narrated by Muslim and Ibn Majah)

The hadiths and verses of the Qur'an already illustrate that as humans we must be able to respect and appreciate one another because Allah SWT created them with commensurate conditions. As for the task of humans that Allah SWT created with normal conditions without limitations, they must protect, help and guide those whom Allah SWT has given limitations so that their potential can be seen. 
Currently, in Indonesia, various educations for children with special needs and persons with disabilities have received attention and have received the spotlight as seen by the opening of various inclusive educational institutions and the placement of persons with disabilities to be able to work in various lines of society and the Government. People with disabilities who are deaf are now starting to get access to information through Sign Language translator snippet seen in the corner of the television screen in news programs on both Public and Private Television Stations. Unfortunately, there was no sign language translator for Islamic studies on both public and private television shows. Access for the deaf to obtain Islamic studies was few and very limited. This certainly had an impact on the rights of those who should receive religious education from an early age, which became an obstacle.

In several previous studies, which have been carried out including regarding learning to pray for deaf children at Gerkatin Surakarta, which states that in order to maximize the prayer learning program for deaf children based on Indonesian sign language, it is necessary to develop a more structured model so that program implementation can be in accordance with goals (Faqih Annisa: 2019). Then the second research was conducted by Mega Rizki regarding PAI (Islamic Religious Education) learning at SMPLB Category B for the deaf, in this study it can be concluded that the PAI learning process at SMPLB-B Negeri Ungaran uses the 2013 Curriculum with a scientific approach which is generally applied in schools. general evaluations, as well as evaluations carried out on PAI learning at SMPLB-B Negeri Ungaran using an assessment that must be followed, namely UTS and UAS (Mega Rizki: 2020). This research is considered important because the process of developing Islamic values that are included in learning at The Little Hijabi Home Schooling institution and instilling Islamic values in deaf children starts from an early age. The Little Hijabi Homeschooling is the only school that educates deaf students with a deeper understanding of Islam because early childhood is taught about monotheism as well as the history and stories of the Prophet. The Little Hijabi, located in Bekasi, West Java, is homeschooling that used Sign Language as an introduction for deaf students. The learning carried out in conveying the contents of the Qur'an and the story of the Prophet also used sign language.

Research that has been done shows that the barriers that exist in hearing will look for quite complex problems including perception, language and communication, cognitive, emotional, social, job acquisition as well as for parents and society (According to Bothryod in Hermanto, 2011). According to Toe \& Paatsch (2010), another obstacle for the deaf is their limited social environment so that they become like people who cannot influence.

In reality, early childhood children who have limited deafness have very little understanding in terms of religion. When early childhood who are in the normal category can say thoyibah sentences, memorize prayers, and recognize hijaiyah letters. It is different, of course, with deaf children who are limited in visual media in religious learning, teaching staff who understand sign language, and the environment that forms monotheism for deaf children. Early age is the most important phase in shaping individual personality because at this phase good values must be instilled into the child's soul (Shabrina: 2020). The character that is instilled from religious education from an early age will be embedded and shape the child's personality so that it becomes a useful child. Of course, the obstacles experienced by deaf children can be minimized from the various activities carried out at The Litte Hijabi Home Schooling.

\section{METHODOLOGY}

This study used a qualitative approach. The research location is located in Bekasi, West Java. Researchers explored data related to the development of Islamic values carried out by the Chairperson of the Foundation, Principals, Teachers, and also parents. This study also used the observation method by collecting data, information, and studying existing records as well as literature studies by studying various references related to information related to research 
through browsing and literature review in order to better support the object of a study by comparing existing theory with existing practice at the data source location.

Data analysis techniques in this study use data reduction, data presentation, and conclusions or verification by creating themes. There are five themes that emerge, namely, a) the introduction of the study of prayer, b) the introduction of monotheism, c) the introduction of the sentences thayibah and iqro in sign language d) the activities of the Board Games of the Story of the Prophet with sign language. The steps of research activities can be seen in the chart 1.

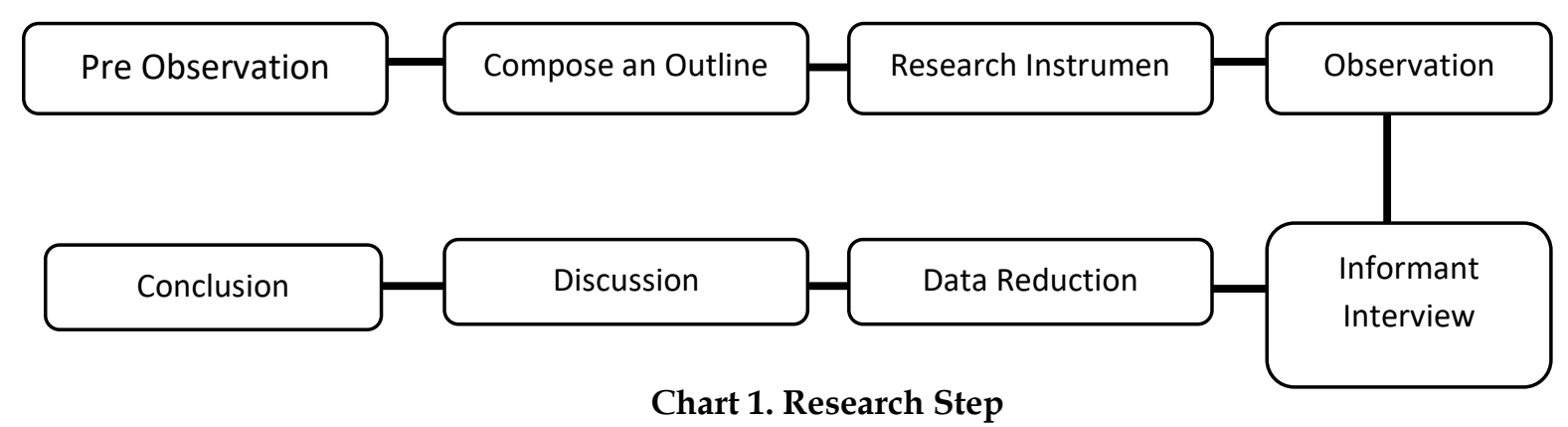

\section{RESULT AND DISCUSSION}

Deaf is a term given to individuals who experience a lack or loss of the ability to hear either partially or completely as a result of the malfunctioning of the sense of hearing or impaired hearing nerves. These fast hand movements are a means of communication for the deaf.

According to Donal F. Morees in Winarsih (2007), defined deaf as "hearing impairment a generic term indicating a hearing disability that may range in severty from mild to profound it concludes hearing disability preclude succesfull processing of linguistic information through audition, with or without a hearing aid. A hard of hearing is one who generally with use of hearing aid, his residual hearing sufficient to enable succesfull processing on linguistic information". From this definition, it can be interpreted that deaf is a general term that indicates hearing difficulties or deaf who has hearing loss.

This condition causes the deaf to have distinctive characteristics, different from normal children in general. Some of the characteristics of deaf children include: 1) In Terms of Physical can be seen by stiff gait and slightly bent due to problems with the balance organ in the ear. That is why deaf children experience a lack of balance in their physical activities. Then their breathing is short and irregular, this is because deaf children never listen to sounds in everyday life because they don't know how to sound or pronounce words with good intonation, so they are also not accustomed to regulating their breathing properly, especially in speaking (Bianco, 2020). 2) How to see. This is because sight is one of the most dominant senses for deaf children because most of their experience is obtained through sight. Therefore, deaf children are also known as visual children, so the way they see them always shows great curiosity (de Boer \& Munde, 2015); 3) In Terms of Language, it can be seen from the vocabulary that they have not much. Then the difficulty in interpreting words that contain expressions or idiomatic as well as their grammar is less regular. ; 4) Intellectual, actually the intellectual ability of deaf children is normal because basically, deaf children do not experience problems in intellectual terms. However, due to limitations in communication and language, their intellectual development becomes sluggish which also results in slow academic development due to language limitations (Friend \& Bursuck, 2015). Often the occurrence of lags in intellectual development due to obstacles in communication, in terms of academics, deaf children also experience delays; 5) Socio-Emotional, which can be seen from the frequent occurrence or feelings of suspicion and prejudice. This attitude occurs as a result of impaired hearing function. They cannot understand what other people are talking about so deaf 
children become suspicious easily. And they are more often aggressive because they feel they can't interpret what other people are saying.

Deaf children also experience abnormalities in their hearing function, causing obstacles in communicating with people who can hear. This of course can hinder the development of its potential. Likewise, what we see directly in communicating, often the message conveyed by the resource person cannot be fully received by the recipient of the message due to several factors. This also happens to deaf Muslims, especially early childhood children in studying Islamic religious lessons (Bazna \& Hatab, 2005). Religious education is an effort and the only way how the human process can know God and religion as a whole from an early age until the end of life. Therefore, it is necessary to develop Islamic values for deaf students, especially so that they can know religion from themselves and know their religion as a whole, not halfway and must be thorough (Dhyanti, Junaedi, \& Sukayat, 2020). Islam is a perfect religion, Islam has a way of life that regulates all sides of life without exception, including people with disabilities who Allah SWT has destined to have limitations (Wahono, 2017). In accordance with the words of Allah SWT and the Hadith of the Prophet Muhammad SAW which explained clearly that the rights of every human being are equal, including in obtaining education and knowing their God (Syaibani, 1979).

The Little Hijabi was originally built as a learning house specifically for deaf children. Then The little hijabi homeschooling developed into a school where the leaders, teachers, and cleaning staff were deaf. This institution was founded by Galuh Sukmara Soejanto in 2013 which started from her indecision and anxiety that had lasted for 30 years because she did not have access to learning Islam. Galuh, who studied at the Faculty of Psychology, Gadjah Mada University (UGM) and continued her studies at La Trobe University, Melbourne, Australia, majoring in Master of Sign Linguistics. Galuh was inspired by Gallaudet University, Washington, D.C., United States, which is the only university in the world dedicated to students who are deaf or hearing impaired people. The oldest university for the deaf in the world is filled with many deaf people, from the rector, lecturers, to students. A sign that is the nature of deaf children. Besides being taught how to read the Qur'an, the deaf Muslim also need to be given a good understanding of Islam about how to sound the adhan, how to pray, hajj, stories of the Prophets, and others. Therefore, The Little Hijabi developed an Islamic learning media through board games for the first time in Indonesia using sign language. This media was named 'Kisah Dalam Isyarat' (KDI) or 'Stories in Signs' and was supported by video tutorials on learning the Qur'an and Islam in sign language. The little hijabi homeschooling has students who vary in terms of age, but this is what makes deaf students complement each other and are always enthusiastic when socializing. The little hijabi homeschooling carried the bilingual concept, namely Indonesian Sign Language (BISINDO) and Indonesian (Indra, Madenda, \& Wibowo, 2019). Sign Language was used as the main language of introduction to learning and the first in Indonesia to apply the concept.

The Little Hijabi Homeschooling has the principle that Deaf students will be more comfortable in learning if taught by teachers who have the same condition, namely Deaf. The Story Telling system using sign language is superior in learning, especially using the stories of the Prophet and Islamic stories. It was intended that students can realize that their duty as humans is to worship Allah SWT. Students who are at an early age, from the beginning have been taught the habit of worship by walking to the mosque when the midday prayer arrives. They were also taught from an early age (kindergarten age) to recognize Arabic letters using sign language. The little hijabi homeschooling also taught the adhan and reading the Qur'an using sign language.

The Little Hijabi Home Schooling innovates in Shiroh Nabawiyah's learning through KDI (Kisah Dalam Isyarat) board games as shown in Figure 1. and in Figure 2, a deaf child is reading a letter in the Koran in sign language, and in Figure 3, the teacher is doing the Prophet's Storytelling Activities by Deaf Teachers to Students by using picture media. 
Development of Islamic Values for Deaf Students at Little Hijabi Homeschooling DOI: 10.31004/obsesi.v6i3.1999

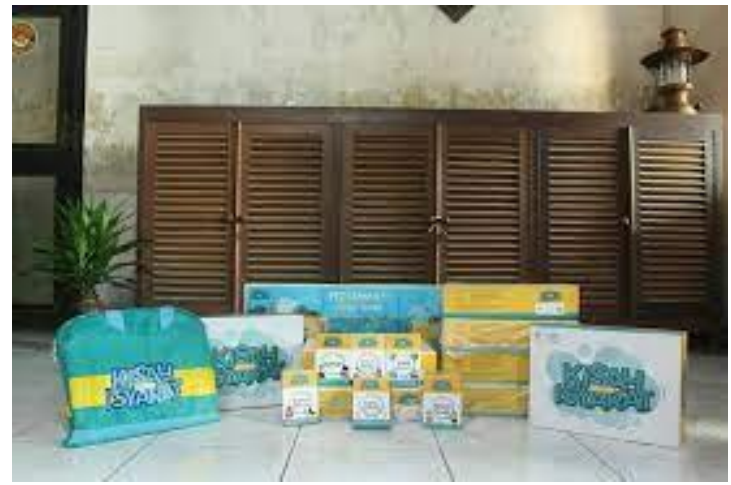

Figure 1. Board Games Stories in Signs
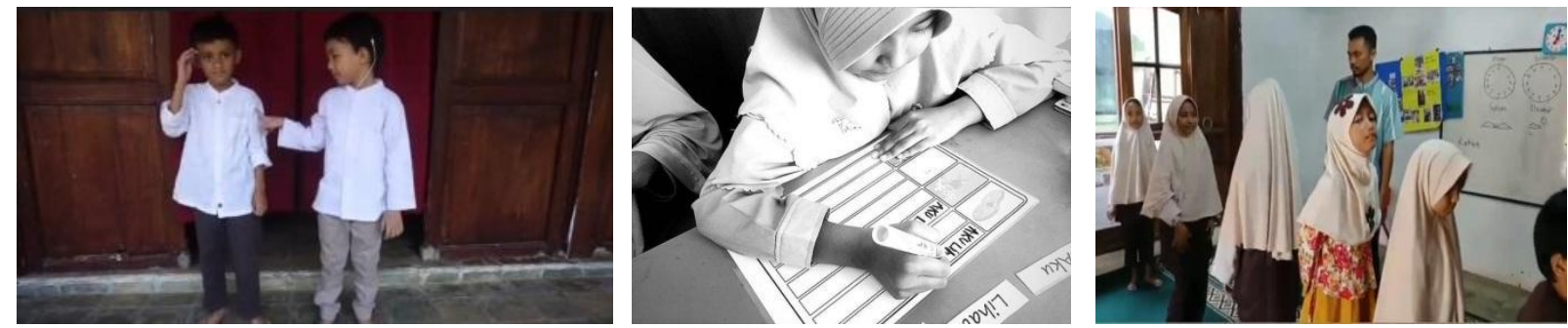

Figure 2. Learning activities with Sign Language and instilling Islamic values
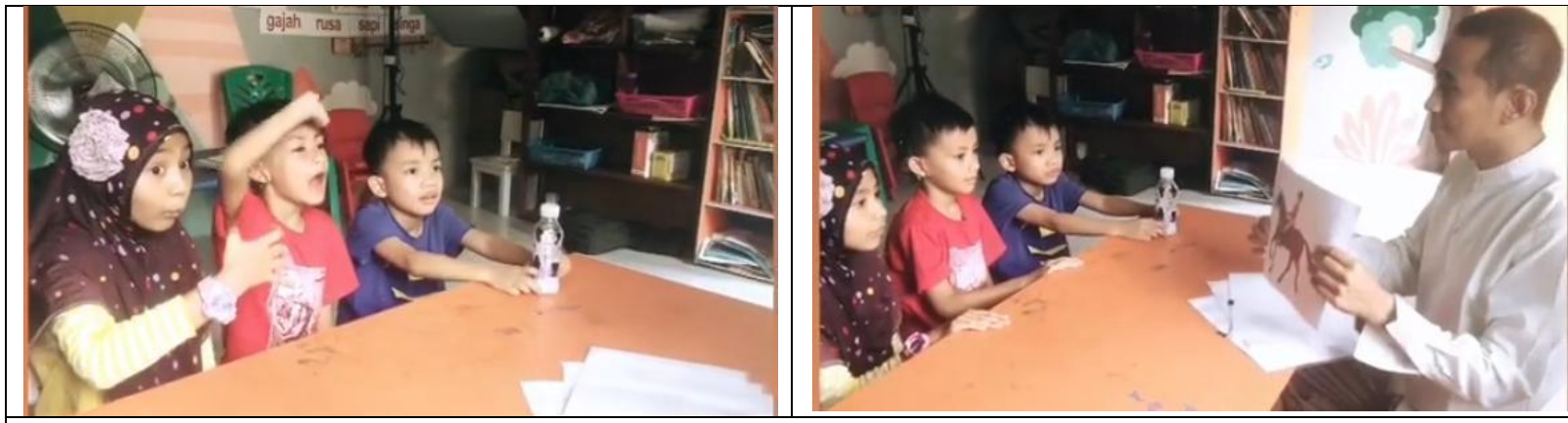

Figure 3. The activity of telling the story of the Prophet by a Deaf Teacher to Students using picture media

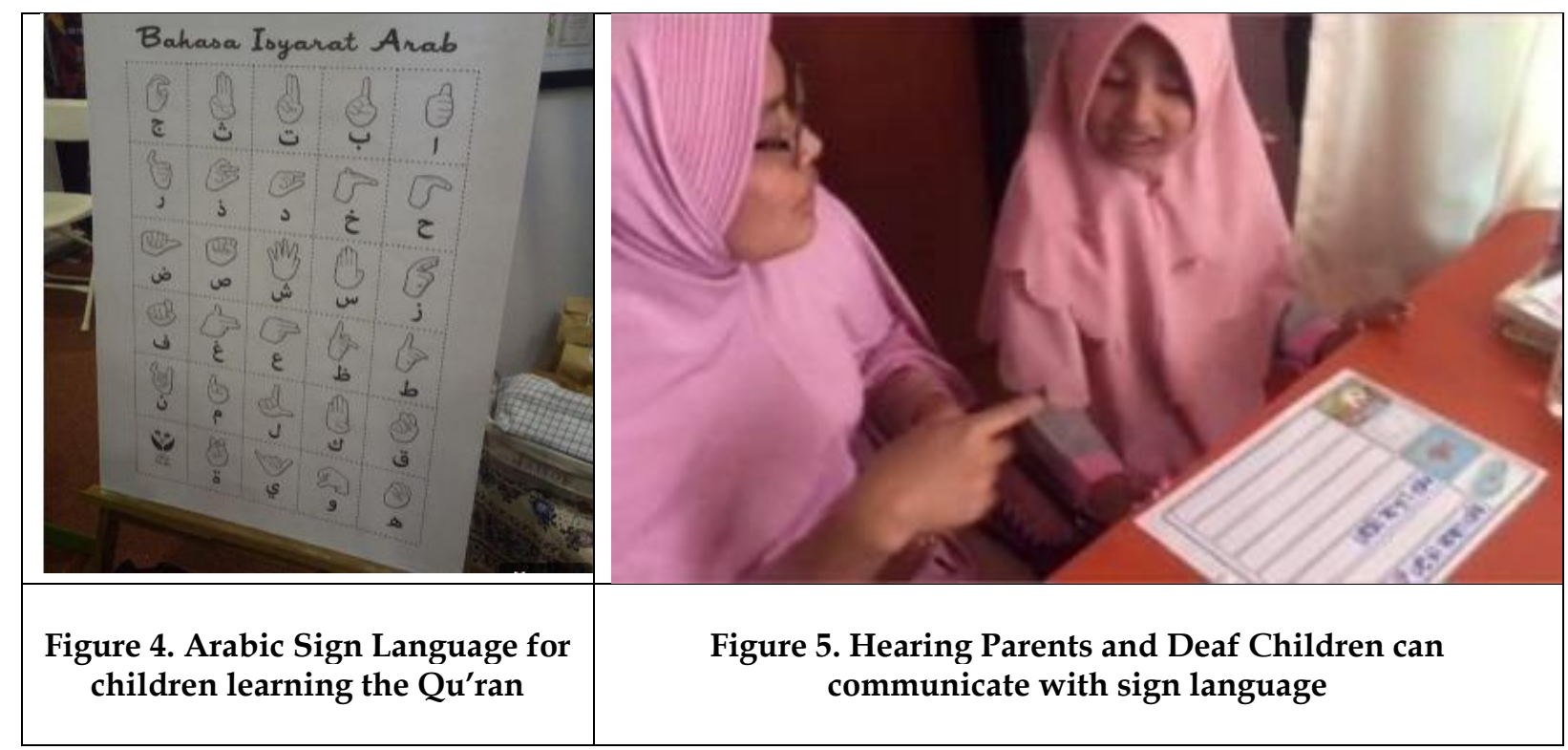


Teacher learning and guidance in instilling Islamic values can be done through various approaches. Several approaches were taken in daily life and learning, namely a) monotheism, by providing understanding and opportunities for students to be able to know Allah SWT through His creation and make it a source of life for creatures; b) habituation, is certain behavior that is automatic without being planned in advance and just happens that sometimes without thinking. This was carried out by instilling prayer and Islamic etiquette in daily habits such as being patient, honest, and doing good to Allah's creatures (Wulan, 2020); c) rational, namely an approach that used ratio (reason) in understanding and accepting religious teaching. This was applied by explaining the love of Allah SWT by creating all creatures and the history of the Prophets that can be learned from; d) functional, namely an approach that emphasizes the benefits for students in everyday life, useful and beneficial for students both in individual life and in social life. This functional activity is applied through student talent activities which were fully supported by parents and schools to be able to benefit the environment such as making soap which can then be sold and benefit the surrounding environment; e) emotional, providing self-maturation through the sense of power it has so that it has a high sense of empathy and sociality. This was evidenced through the emotional approach conveyed through the stories of the Prophet who were full of examples and traits that can be imitated in everyday life. The Little Hijabi Homeschooling is not only for deaf students. There are some students who suffer from down syndrome or have other limitations who attend school and have positive developments in their stages of development and learning.

Galuh as the chairperson of the foundation of The Little hijabi homeschooling revealed that homeschooling can be applied in their respective homes by involving parents as the main educators for a deaf child. Because the main purpose of establishing The little hijabi homeschooling was to be able to establish good communication between parents and deaf children. On the other hand, the creation of good communication will actually train parents to increase their ability and independence in educating. In addition, through this, parents can urge their children to be closer to Allah SWT through the rituals of worship taught at The Little Hijabi which were applied at home. The research location mentioned by the researcher has never been done before and the discussion on the development of Islamic values in deaf early childhood has not been carried out by other researchers

\section{RESULTS AND DISCUSSION}

The results of research conducted by Sri Sulastri that research on learning Islamic Religious Education in deaf children shows that deaf students have carried out religious rituals in daily life and behave like religious guidance, namely students the deaf are very polite, friendly and used to doing ablution and praying. However, there are several obstacles experienced including: lack of teachers of Islamic religious education, lack of use of media, lack of student discipline. Child deaf people have difficulty interpreting abstract concepts and lack the ability to communicate so that teachers train in improving language using sign language, writing, speaking and spelling, or a mixture of all of them. Research conducted by Heryanti Dewi entitled implementation of islamic religious education for children with special deaf needs in school extraordinary at Bengkulu province, the results of the study explain that planning, implementation, and learning outcomes of ablution procedures for deaf children can be carried out well but the material is lighter. One of the novelties in this research is the research location which is the only school that is engaged in the deaf and instills Islam from an early age and teaches understanding through sign language to parents so that the delivery of messages from deaf children can be understood so that communication between children and mothers can be well established. and children's emotions can be stable. 
From the data obtained through Mrs. Galuh as the owner of the foundation, the researchers obtained data that the learning approaches or methods used coupled with Islamic values made deaf students able to have excellent abilities and achievements, especially in the religious field. Deaf students who attended The little hijabi homeschooling have known monotheism from an early age which was different from other deaf early age children who had difficulty in obtaining access to know Islam because of the lack of places to learn Islam by using sign language.

This is because various programs implemented at The Little Hijabi Home Schooling support the learning process, namely 1) Stories in Signs through Board Games; 2) Reading Iqro with sign language; 3 ) The approach of parents and deaf children in understanding sign language together so that good communication can be established and increase children's confidence.

The purpose of sign language is to help communication between two parties which cannot be done through spoken words. This is not limited to the deaf or mute, but can also be used for children with normal hearing and speaking abilities. Some deaf people used hearing aids or cochlear implants. However, with sign language, they will be more helpful in understanding speech and communicating with others, besides that sign language can also help strengthen relationships and train children's communication skills from an early age. As for communication with parents, it can be built well because, at The little hijabi homeschooling, parents were taught to communicate with sign language in order to help communication between parents and children as well as the delivery of messages can be well received between both parties.

\section{CONCLUSION}

The conclusion of this research is the development of Islamic values in deaf students at The Little Hijabi Homeschooling was carried out with various approaches, namely 1) The monotheism approach through board games entitled Stories in Signs (KDI) which is an innovation for deaf children in understanding Islam 2) Parent and Child approaches in communicating so that Deaf children can grow their confidence and can adapt to others because they feel that he is understandable; 3) Make the institution a second home for deaf children and other disabilities because of the presence of teachers who have the same problem and do not feel alone so that the inculcation of Islamic values can be carried out and being deaf children can study Islam as children in general.

\section{AKNOWLEDGEMENT}

Thanks to The Little Hijabi Home Schooling and PUSBISINDO who have facilitated researchers so that this article can be published, partners who are willing to participate in research and the Obsession Journal team who have published this article so that it can be read by the public. Hopefully this article is useful both theoretically and practically.

\section{REFERENCES}

Alimin, Z., \& Permanarian. (2005). Reorientasi Pemahaman Konsep Special Education ke Konsep Needs Education dan Implikasinya Layanan Pendidikan. Bandung: Jassi Astiti.

Azizah F.N., (2014). Pemerolehan Kosakata Anak Usia 3-5 Tahun Di Paud Kelompok Bermain Inklusif Anak Ceria Universitas Airlangga. Skriptorium, Vol. 1 (3), hal.57- 66

Bazna, M. S., \& Hatab, T. A. (2005). Disability in the Qur'an: The Islamic alternative to defining, viewing, and relating to disability. Journal of Religion, Disability \& Health, 9(1), 5-27. https://doi.org/10.1300/J095v09n01_02 
Bianco, J. Lo. (2020). Ideologies of sign language and their repercussions in language policy determinations. Language \& Communication, 75, 83-93. https://doi.org/10.1016/j.langcom.2020.09.002

De Boer, A. A., \& Munde, V.S. (2015). Parental attitudes toward the inclusion of children with profound intellectual and multiple disabilities in general primary education in the Netherlands. The Journal of Special Education, 49(3), 179-187. https:// doi.org/10.1177/0022466914554297

Dhyanti, D. R., Junaedi, J., \& Sukayat, T. (2020). Bahasa Isyarat Dalam Memahami Bacaan Shalat Pada Anak-anak Tunarungu. Tabligh: Jurnal Komunikasi Dan Penyiaran Islam, 5(2), 112-129. https:// doi.org/10.15575/tabligh.v5i2.1775

Faqih, Annisa. (2019). Pengembangan Model Pembelajaran Salat Berbasis Bahasa Isyarat Indonesia (Bisindo) Di Organisasi Gerakan Kesejahteraan Untuk Tuna Rungu Indonesia (Gerkatin) Surakarta Tahun 2019. Tesis. Salatiga. Institut Islam Negeri Salatiga.

Friend, M., \& Bursuck, W. D. (2015). Menuju Pendidikan Inklusif (Panduan Praktis untuk Mengajar). Yogyakarta: Pustaka Pelajar.

Hermanto.2011.Penguasaan Kosa Kata Tunarungu dalam Pembelajaran Membaca melalui penerapan Metode Maternal. Majalah Ilmiah Pembelajaran Vol 7 (2),hal 120- 135

Indra, D., Madenda, S., \& Wibowo, E. P. (2019). Indonesian Sign Language Recognition Based on Shape of Hand Gesture. Procedia Computer Science, 161, 74-81. https://doi.org/10.1016/j.procs.2019.11.101

Rizki, Mega. (2020). Pembelajaran Pendidikan Agama Islam Bagi Anak Penyandang Tunarungu Di Smplb Negeri Ungaran Tahun Ajaran 2019/2020. Skripsi. Salatiga. Institut Islam Negeri Salatiga

Shabrina, Nur Monita., Nur Azizah., Muhammad Zuhad Rifqi. (2020). Pembelajaran Tahfidz sebagai Media Menumbuhkan Karakter Tanggung Jawab pada Anak Temper Tantrum. Obsesi : Jurnal Pendidikan Anak Usia Dini. https:// doi.org/10.31004/obsesi.v4i2.511

Syaibani, A. O. M. al toumy. (1979). Falsafah Pendidikan Islam. Jakarta: Bulan Bintang.

Wahono, B. M. (2017). Menyiarkan Islam Kepada Kaum Tunarungu Sidoarjo. Retrieved August 15, 2021, from https://lokadata.id/artikel/menyiarkan-islam-kepada-kaumtunarungu

Winarsih, M. (2007). Intervensi dini bagi anak tunarungu dalam pemerolehan bahasa. In Jakarta: Depdiknas. Jakarta: Depdiknas.

Wulan, A. (2020). Penanaman Nilai Agama Islam Terhadap Anak Berkebutuhan Khusus Di Sekolah Luar Biasa Negeri Muara Bungo. Skripsi. Universitas Islam Negeri Sultan Thaha Saifuddin Jambi. 